\title{
MEMBANGUN INKLUSIVITAS KEBERAGAMAAN ANTARA MASYARAKAT DENGAN PENYANDANG TUNA DAKSA MELALUI BIMBINGAN FIKIH IBADAH DI “RUMAH KASIH SAYANG” DESA KREBET JAMBON PONOROGO
}

\author{
Afif Syaiful Mahmudin \\ Institut Agama Islam Negeri (IAIN) Ponorogo \\ afifsyaifulmahmudin7@yahoo.co.id
}

\begin{abstract}
Persons with physical disabilities recorded under the auspices of the "Rumah Kasih Sayang" institution are 12 people. Ideally, the practice of worship should be carried out easily by everyone, but in fact there are still many people with disabilities who experience difficulties in implementing it, not even a few of them have left worship because of low religious-related understanding and lack of motivation from the community to include persons with disabilities. carry out daily worship obligations. These problems are experienced by people with disabilities, especially physically disabled in the "Rumah Kasib Sayang" in Krebet village. People with disabilities by the community are considered as groups who are no longer obliged to worship, they are sufficiently fostered with a variety of skills obtained from the institution, empowered by breeding goats from compensation without even being physically invited to pray together in the mosque or prayer room. Religious inclusiveness needs to be built between the community and the physically disabled, the community must be given an understanding that as long as the disabled person meets the taklif provisions, there is no privilege that disqualifies the obligation of worship for the disabled.The research questions are: 1) What are the implications of the figh guidance of worship for the disabled in the "Rumah Kasib Sayang" Krebet Jambon Village? 2) What are the implications of fiqh material for worship for the people of Krebet Jambon Village ?. To answer the formulation of the problem, the researcher used a Participatory Action Research (PAR) approach. The results of this study are: 1) Deaf people can practice well the procedures of daily worship in accordance with the fiqh hospitality of disabled people while being able to carry out the obligation to worship together with the surrounding community. 2) People get new insights about fiqh worship for people with disabilities, changing their negative stigma towards disabled people and leading to the realization of an inclusive religious culture in Krebet Jambon Ponorogo Village.
\end{abstract}

Keywords: Inclusive, Religion, Society and Disability.

\section{Abstrak}

Penyandang tuna daksa yang tercatat dibawah naungan lembaga "Rumah Kasih Sayang" berjumlah 12 orang. Idealnya, praktik beribadah harusnya dapat dilakukan dengan mudah oleh semua orang, tetapi faktanya bagi penyandang difabilitas masih banyak yang mengalami kesulitan dalam pelaksanaannya, bahkan tidak sedikit dari mereka yang sampai meninggalkan ibadah sebab rendahnya pemahaman terkait keagamaan maupun minimnya motivasi dari masyarakat untuk mengikutsertakan penyandang difabel dalam menjalankan kewajiban ibadah sehari-hari. Permasalahan tersebut dialami oleh penderita difabel khususnya tuna daksa di "Rumah Kasih Sayang" desa Krebet. Penyandang tuna daksa oleh masyarakat dianggap sebagai golongan yang tidak lagi wajib menjalankan ibadah, mereka cukup dibina dengan berbagai keterampilan yang didapat dari lembaga, diberdayakan dengan mengembangbiakkan kambing dari hasil santunan tanpa sekalipun para tuna daksa tersebut diajak bersama-sama sholat berjama'ah di masjid ataupun mushola. Inklusivitas 
keberagamaan perlu sekali dibangun antara masyarakat dengan penyandang tuna daksa, masyarakat harus diberi pemahaman bahwa selama penyandang tuna daksa tersebut memenuhi ketentuan taklif, maka tidak ada hak istimewa yang menggugurkan kewajiban beribadah bagi kaum difabel (tuna daksa). Yang menjadi pertanyaan penelitian adalah: 1) Bagaimana implikasi bimbingan fikih ibadah bagi tuna daksa di "Rumah Kasih Sayang" Desa Krebet Jambon? 2) Bagaimana implikasi materi fikih ibadah bagi masyarakat Desa Krebet Jambon?. Untuk menjawab rumusan masalah tersebut, peneliti menggunakan pendekatan Participatory Action Research (PAR). Hasil dari penelitian ini adalah: 1) Para tuna daksa dapat mempraktikkan dengan baik tata cara beribadah sehari-sehari sesuai dengan keramahan fikih difabel sekaligus dapat menjalankan kewajiban beribadah bersama dengan masyarakat sekitar. 2) Masyarakat mendapatkan wawasan baru tentang fikih ibadah bagi kaum difabel, mengubah stigma negatif mereka terhadap penyandang tuna daksa dan berujung pada terwujudnya kultur keberagamaan yang inklusif di Desa Krebet Jambon Ponorogo.

Katakunci: Inklusif, Keberagamaan, Masyarakat dan Tuna Daksa

\section{PENDAHULUAN}

Belum terwujudnya perlakuan dan perhatian yang sama dalam pemenuhan hak bagi difabilitas merupakan salah satu dari problem kemanusian kontemporer, termasuk dalam hal ibadah. Sejatinya difabilitas adalah kehendak Allah dan menjadi ujian yang harus diterima, oleh karena itu selama memenuhi ketentuan taklif tidak ada hak istimewa yang menggugurkan kaum difabel dalam menjalankan kewajiban agama seperti ibadah sehari-hari.

Idealnya, praktik beribadah harusnya dapat dilakukan dengan mudah oleh semua orang, tetapi faktanya bagi penyandang difabilitas masih banyak yang mengalami kesulitan dalam pelaksanaannya, bahkan tidak sedikit dari mereka yang sampai meninggalkan ibadah sebab rendahnya pemahaman terkait persoalan agama terutama tentang fikih ibadah seperti tatacara ibadah yang baik mulai dari bersuci, wudlu, sholat dan lain sebagainya. Penyebab lainnya ialah minimnya motivasi dari masyarakat untuk mengikutsertakan penyandang difabel dalam menjalankan kewajiban ibadah sehari-hari.

Permasalahan tersebut dialami oleh komunitas penyandang disabilitas di "Rumah Kasih Sayang” Desa Krebet Kecamatan Jambon Ponorogo khususnya bagi penyandang tuna daksa. Rumah Kasih Sayang adalah sebuah lembaga yang didirikan tahun 2011 oleh Kementerian Sosial untuk menaungi dan memberdayakan penyandang tunagrahita dan penyandang disabilitas jenis lain termasuk tuna daksa. Tempat ini bukan berupa panti sosial yang ditinggali oleh penyandang difabel, tetapi merupakan wadah untuk memberdayakan penyandang disabilitas dalam bimbingan karir dan keterampilan yang dilaksanakan dua kali dalam sepekantepatnya hari jum'at dan minggu, yang sangat disayangkan ialah persoalan keagaaman belum pernah diberikan sama sekali kepada penderita difabel khususnya masalah praktik ibadah harian. Setelah kegiatan maupun pembinaan selesai penyandang difabel akan pulang kerumah masing-masing. ${ }^{1}$

${ }^{1}$ Wawancara dengan Bapak Zainuri sebagai Ketua Pengurus Rumah Kasih Sayang pada hari Sabtu 23 Juni 2018 pukul 10.30 WIB 
Penyandang difabilitas yang terdaftar aktif di "Rumah Kasih Sayang" Desa Krebet terdapat 33 orang seperti yang ditunjukkan dalam tabel 1 berikut ini:

Tabel 1. Daftar Penyandang Difabilitas "Rumah Kasih Sayang"

\begin{tabular}{|l|l|l|c|c|c|}
\hline \multirow{2}{*}{ No } & \multicolumn{1}{|c|}{$\begin{array}{c}\text { Penyandang } \\
\text { Difabilitas }\end{array}$} & \multicolumn{1}{|c|}{ Keterangan } & \multicolumn{2}{|c|}{ Jumlah } & \multirow{2}{*}{ Total } \\
1. & Tunagrahita & $\begin{array}{l}\text { Cacat pikiran, lemah } \\
\text { daya tangkap (idiot) }\end{array}$ & 9 & 13 & 22 \\
\hline 2. & Tunadaksa & $\begin{array}{l}\text { Cacat tubuh dan } \\
\text { gangguan gerak }\end{array}$ & 8 & 4 & 12 \\
\hline 3. & $\begin{array}{l}\text { Tunarungu- } \\
\text { wicara }\end{array}$ & $\begin{array}{l}\text { Tidak dapat bicara } \\
\text { (bisu) dan } \\
\text { mendengar (tuli) }\end{array}$ & 5 & 2 & 7 \\
\hline 4. & Tunanetra & $\begin{array}{l}\text { Tidak dapat melihat } \\
\text { (tuli) }\end{array}$ & 2 & - & 2 \\
\hline 5. & Tunalaras & $\begin{array}{l}\text { Cacat suara dan } \\
\text { nada }\end{array}$ & 3 & 6 & 9 \\
\hline
\end{tabular}

Tabel 2. Prevalensi Penyandang Difabilitas "Rumah Kasih Sayang”

\begin{tabular}{|l|l|c|c|c|}
\hline \multirow{2}{*}{ No } & \multicolumn{1}{|c|}{$\begin{array}{c}\text { Penyandang } \\
\text { Difabilitas }\end{array}$} & \multicolumn{2}{c|}{ Jumlah } & \multirow{2}{*}{ Total } \\
\cline { 2 - 4 } & \multicolumn{1}{|c|}{ Lk } & Pr & \\
\hline 1. & Anak-anak/Remaja & 3 & 9 & 11 \\
\hline 2. & Dewasa & 11 & 26 & 37 \\
\hline 3. & Lansia & 1 & 3 & 4 \\
\hline \multicolumn{2}{|c|}{ Total } & $\mathbf{5 2}$ \\
\hline
\end{tabular}

Selain penyandang difabel di "Rumah Kasih Sayang” juga memiliki 12 orang kader pendamping yang bertugas membimbing, melatih dan memberdayakan para penderita dengan kegiatan-kegiatan yang dilaksanakan rutin setiap minggu serta memasak dan mengirim nasi bungkus untuk tiga kali makan setiap harinya dengan dua kali pengantaran yaitu pukul 08.00-09.00 WIB dan pukul 15.00-16.00 WIB ke masing-masing rumah penyandang difabilitas. ${ }^{2}$

Di "Rumah Kasih Sayang" tersebut baik penyandang tuna daksa maupun keluarga pasien semuanya beragama Islam. Permasalahan yang dihadapi khususnya bagi tuna daksa ialah sulitnya melaksanakan rutinitas ibadah yang menjadi kewajibannya. Hal ini bukan tanpa sebab, faktor-faktor yang menciptakan situasi tersebut diantaranya pertama, rendahnya pemahaman akan fikih ibadah dalam diri penyandang tuna daksa, mereka menganggap fikih hanya diperuntukkan bagi manusia normal yang sempurna fisik dan psikisnya. Kemauan

${ }^{2}$ Dokumentasi di Rumah Kasih Sayang pada hari Sabtu 23 Juni 2018 pukul 10.30 WIB.

16| Afif Syaiful Mahmudin, - Membangun Inklusivitas Keberagamaan 
untuk meningkatkan pemahaman fikih ibadah sama sekali tidak pernah diinginkan oleh mereka melihat kondisi penderita yang serba terbatas. Kedua, kurangnya pengetahuan tentang fikih ibadah yang ramah bagi difabilitas secara menyeluruh dan komprehensif bagi para kader pendamping di "Rumah Kasih Sayang" tersebut. Hal ini sebenarnya wajar karena keduabelas orang yang bertugas membimbing pasien berlatar belakang umum. Para kader kurang mengetahui bagaimana tatacara wudlu bagi klien yang kehilangan tangannya, praktik sholat fardlu baik sendirian maupun jamaah bagi penyandang tuna daksa dan lain sebagainya. Ketiga, stigma negatif masyarakat kepada penyandang tuna daksa di "Rumah Kasing Sayang".Pandangan negatif tersebut sangat luas jenjangnya, dari yang dianggap baik, seperti proteksi yang berlebihan dan pemberian bantuan karena kasihan, hingga tindakan diskriminatif yang mengakibatkan hak-hak pengajaran fikih ibadah tidak pernah diberikan kepada penyandang tuna daksa. Perubahan ini harus dilakukan secara bertahap untuk mengubah stigma yang dibangun oleh masyarakat, bahwa penyandang tuna daksa tidak memiliki manfaat bagi kehidupan dan hanya menjadi beban bagi kaum normal. Jika masyarakat bersikeras untuk terus mempertahankan perilaku eksklusif ini tentunya jurang pemisah antara kaum difabel dan non-difabel akan semakin melebar, maka sampai kapanpun penyandang tuna daksa tidak akan mendapatkan haknya dalam belajar fikih apalagi mampu mengenyam pendidikan tinggi.

Fungsi fikih ibadah sendiri adalah membimbing dan memberikan solusi permasalahan ibadah praktis yang bersifat individual maupun sosial. fikih bersifat luwes bahkan bagi penyandang tuna daksa sekalipun, hal ini sesuai kaidah dalam fikih klasik yang menyatakan "al-Masyaqqah Tajlib al-Taisir" suatu kesulitan dalam melaksanakan perbuatan dapat menarik kemudahan. Maka, tidak ada alasan lagi bagi kita untuk tidak memperhatikan kebutuhan penyandang tuna daksa dalam menjalankan kewajiban agama. Disamping juga harus mendapat dukungan lingkungan sekitarnya serta tersedianya aksesibilitas fisik maupun nonfisik.

Melihat kondisi yang terjadi, maka sangat tepat untuk melakukan penelitian terkait inklusivitas keberagamaan antara penyandang tuna daksa dengan masyarakatmelalui kegiatan praktik fikih ibadah di "Rumah Kasih Sayang” Desa Krebet Kecamatan Jambon. Hasil penelitian ini nantinya diharapkan mampu menigkatkan pemahaman secara komprehensif tentang fikih ibadah dan mampu mempraktikkan ibadah secara mudah bagi tuna daksa di tempat tersebut dan peran serta seluruh elemen masyarakat juga diperlukan dalam rangka mengubah stigma negatif mereka terhadap penyandang tuna daksa.

Yang menjadi pertanyaan penelitian adalah: 1) Bagaimana implikasi bimbingan fikih ibadah bagi tuna daksa di "Rumah Kasih Sayang" Desa Krebet Jambon? 2) Bagaimana implikasi materi fikih ibadah bagi masyarakat Desa Krebet Jambon?. Untuk menjawab rumusan masalah tersebut, peneliti menggunakan pendekatan kualitatif dengan jenis studi kasus.

Berdasar observasi peneliti, ada beberapa alasan mengapa penyandang tuna daksa di "Rumah Kasih Sayang"serta masyarakat Desa Krebet Kecamatan Jambon ini kami jadikan obyek penelitian, Pertama, obyek tuna daksa sangat memerlukan pembinaan. Mengingat 
kegiatan bimbingan yang berkaitan dengan aspek ruhani (khususnya fikih ibadah) belum pernah diberikan. Padahal sebagai hamba Allah adanya berbagai kekurangan baik fisik ataupun mental bukan berarti dapat menggugurkan kewajiban beribadah. Kedua, pembinaan fikih ibadah (khususnya taharah dan sholat fardlu) merupakan ibadah dasar yang harus dikuasai oleh setiap muslim tanpa membedakan cacat fisik ataupun mental dan pastinya ada beberapa keistimewaan dalam tataran rukshob (keringanan) bagi mereka. Ketiga, wilayah kecamatan Jambon khusunya wilayah desa Krebet dan Sidoharjo merupakan wilayah yang memiliki jumlah penyandang difabel yang cukup banyak. Selama ini keberadaan mereka oleh masyarakat masih dipandang sebelah mata bahkan santer terdengar "kampung idiot", dengan adanya berbagai pembinaan, salah satunya adalah fikih ramah difabel lamban laun dan berangsur-angsur mampu menghilangkan stigma negatif tersebut, hal ini juga sejalan dengan gagasan Bapak Zaenuri (Ketua "Rumah Kasih Sayang”) yang berupaya merubah stigma dari "Kampung Idiot" menjadi "Kampung Difabel yang Produktif” dengan adanya pembinaan ini tidak hanya Produktif tapi juga Religius sehingga jargonnya berubah menjadi "Kampung Ramah Difabel yang Produktif, Kreatif dan Religius" diharapkan kedepan penyandang difabel ini tidak ada lagi.

Beberapa hasil penelitian terkait dengan pembinaan tunadaksa menujukkan bahwa pendekatan bermain dapat digunakan untuk meningkatkan gerak kasar tunadaksa ringan, meningkatkan kepercayaan diri individual berkebutuhan khusus karena dengan bermain mengandung banyak unsur yang membangun karakter anak, dan metode ini sangatlah mudah dipraktikan. ${ }^{3}$

Penelitian tentang gambaran penyandang tuna daksa yang bekerja menghasilkan kesimpulan adanya dinamika optimisme yang dimiliki oleh subjek penelitian. Penyandang tuna daksa merasa kepercayaan dirinya meningkat jika sudah mendapatkan pekerjaan atau mampu bekerja seperti orang normal. ${ }^{4}$

Penelitian dari Imelda Pratiwi dan Hartosujono tentang resiliensi tuna daksa nonbawaan. Dalam penelitian ini didapatkan hasil bahwa keempat subjek memiliki kemampuan resiliensi yang baik. Hal ini dapat dilihat melalui kemampuan subjek dalam mengontrol emosi, kemampuan kontrol terhadap impuls, optimisme, kemampuan menganalisis masalah dengan baik, empati, efikasi diri dan juga pencapaian. Faktor-faktor pendukung juga mempengaruhi kemampuan resiliensi keempat subjek yaitu faktor individual, faktor keluarga dan faktor komunitas. ${ }^{5}$

Terkait inklusivitas bagi difabel terdapat penelitian dari Paulus Eko Kristianto yang mengembangkan sikap inklusif melalui dakwah dalam kerangka filosofis Islam kontemporer. Penelitian ini menghasilkan kesimpulan bahwa teks al-Qur'an Hadis serta

\footnotetext{
3 Zandra dwanita widodo, eka ahmad malik p, indarto w, ismaryati. Meningkatkan potensi gerak kasar anak tunadaksa ringan melalui pendekatan bermain. Jurnal Rehabilitasi dan Remediasi Tahun 23, No.1, Juni 2014, hlm. 48.

${ }_{4}^{4}$ Danella Merdiasi. Gambaran Tuna Daksa yang Bekerja. Jurnal NOETIC Psychology, Vol.3, No.2, Juli-Desember 2013, hlm. 182.

${ }^{5}$ Pratiwi dan Hartosujono. Resiliensi pada Penyandang Tuna Daksa non Bawaan. Jurnal Spirits, Vol.5, No.1, November 2014, hhlm. 53.
}

18 | Afif Syaiful Mahmudin, - Membangun Inklusivitas Keberagamaan 
tradisi literatur Islam memandang difabilitas cukup positif, namun implementasi di masyarakat tidak menunjukkan hal tersebut. ${ }^{6}$

Dari beberapa penelitian diatas, peneliti disini ingin memfokuskan tentang pembinaan bagi tuna daksa dan masyarakat melalui bimbingan fikih ibadah dalam rangka mewujudkan inklusivitas keberagamaan di Desa Krebet Jambon Ponorogo.

Sistematika penelitian ini dimulai dari pendahuluan yang berisi latar belakang dan dasar pemikiran, selanjutya peneliti akan mendeskripsikan segenap potensi yang dimiliki secara umum oleh objek pengabdian. Setelah dipaparkan kondisi riil, dilanjutkan dengan paparan kondisi yang diharapkan. Paparan kondisi yang diharapkan mengerucut pada strategi apa yang bisa dilakukan untuk mencapai kondisi harapan tersebut. Selanjutnya paparan tentang pelaksanaan bimbingan fikih ibadah, yakni berisi tentang gambaran kegiatan serta deskripsi hasil kegiatan bimbingan fikih ibadah bagi tuna daksa dan masyarakat di "Rumah Kasih Sayang" dan diakhiri dengan penutup.

\section{KAJIAN TEORI}

\section{Penyandang Tuna Daksa}

Istilah tuna daksa berasal dari kata tuna (kurang) dan daksa (tubuh), jadi tuna daksa ialah orang yang memiliki anggota tubuh kurang sempurna, ${ }^{7}$ tuna daksa juga berarti keadaan kurang atau terganggu sebagai gangguan pada otot, tulang dan sendi sehingga mengurangi kapasitas kenormalan individu untuk mampu mandiri. ${ }^{8}$

Tuna daksa sering disebut juga cacat tubuh, fisik dan ortopedi bukan kecacatan pada inderanya, hal ini mengakibatkan gangguan pada koordinasi, adaptasi, komunikasi, mobilisasi serta gangguan lainnya. ${ }^{9}$

Faktor penyebab tuna daksa sendiri bisa terjadi pada masa sebelum lahir, ketika lahir dan setelah lahir, adapun sebelum kelahiran disebabkan beberapa faktor diantaranya, 1) Infeksi atau penyakit bayi dalam kandungan, 2) Infeksi yangmenyerang ibu dan berdampak pada bayi seperti rubel, typhus abdominolis, 3) Kelainan pada kandungan mengakibatkan peredaran terganggu, tali pusat tertekan dan merusak syaraf otak, 4) Bayi terkena radiasi, 5) Trauma yang dialami ibu.

Faktor penyebab saat lahir meliputi, 1) Proses kelahiran yang terlalu lama, pinggang ibu kecil dan bayi kekurangan oksigen, 2) Penggunaan alat bantu tang ketika melahirkan berakibat pada jaringan syaraf otak bayi, 3) Penggunaan anestasi yang berlebihan. Kemudian faktor pasca kelahiran ialah, 1) Faktor penyakit seperti enchepalis (radang otak), meningitis (radang selaput otak), influenza, diphtheria dan lain sebagainya, 2) Faktor

${ }^{6}$ Paulus Eko Kristianto. Pengembangan Inklusifitas bagi Difabel Melalui Dakwah dalam Kerangka Filosofis Islam Kontemporer. Jurnal Pemberdayaan Masyarakat: Media Pemikiran dan Dakwah Pembangunan, Vol.1, No.2, 2017, hlm. 339. hlm. 504

${ }^{7}$ Tim Penyusun Kamus Pusat Bahasa. Kamus Besar Bahasa Indonesia. (Jakarta: Balai Pustaka, 2005),

${ }^{8}$ Somantri, Sutjihati. Psikologi Anak Luar Biasa. (Bandung: Refika Aditama, 2006). hlm. 121. 2013), hlm. 31.

${ }^{9}$ Asep Karyana. Pendidikan Anak Berkebutuban Khusus Tunadaksa. (Jakarta: PT. Luxima Metro Media, 
kecelakaan seperti lalu lintas, jatuh, benturan dan lain-lain, 3) Pertumbuhan tubuh dan tulang yang kurang sempurna. ${ }^{10}$

Ciri-ciri dari tuna daksa meliputi; 1) Anggota gerak pada tubuh lemah. Kaku atau lumpuh, 2) Mengalami kesulitan gerakan (kurang sempurna, tidak bisa dikendalikan, tidak lentur), 3) Terdapat kecacatan dalam alat gerak, 4) Jari tangan tidak dapat menggenggam dengan baik, 5) Terdapat anggota gerak yang kurang sempurna, 6) Kesulitan duduk, berdiri dan jalan, 7) Tidak terkendali (hiperaktif). Sedangkan implikasi dari aspek psikologis bagi tuna daksa dapat menimbulkan perubahan-perubahan pada tingkah lakunya sebagai kompensasi dari kekurangan ataupun kecacatan fisik. Penyandang tuna daksa cenderung pemalu, rendah diri, sensitif serta memisahkan diri dari masyarakat. Karakteristik psikologis tersebut dapat dikenali dengan ciri-ciri seperti gangguan pada intelektualnya, gangguan pendengaran dan penglihatan, gangguan taktik kinestetik, gangguan persepsi serta gangguan emosi. ${ }^{11}$

\section{Pembinaan Keagamaan}

Pembinaan ialah usaha, kegiatan maupun tindakan yang dilakukan dengan orientasi daya guna dan berhasil guna untuk mendapatkan hasil yang lebih baik. ${ }^{12}$ Pembinaan keagamaan dapat ditinjau dari dua sudut pandang, pertama, sudut pandang pembaharuan ialah menjadikan sesuatu kearah yang baru serta memiliki nilai yang lebih baik bagi kelangsungan hidup yang berkelanjutan. Kedua, sudut pandang pengawasan ialah usaha yang berkeinginan mejadikan sesuatu lebih berdaya guna sesuai dengan kebutuhan yang sudah terencana sebelumnya.

Syarat-syarat dari Pembinaan keagamaan ini meliputi: a) Pendidikan, pembinaan harus memenuhi aspek dari pendidikan diantaranya keterjaminan kebutuhan pokok dan kebutuhan lainnya seperti yang dikemukakan oleh Maslow dalam teori needs. b) Pembinaan moral, pendidikan moral yang paling baik adalah yang berasal dari ajaran agama. Oleh karena itu segala ajaran agama yang mengandung nilai-nilai moral harus diajarkan dan diamalkan sedini mungkin mulai dari lingkungan keluarga, lembaga maupun masyarakat. c) Pembinaan jiwa taqwa, fungsi dari ketaqwaan ialah sebagai pengendalian sikap dan perilaku yang dilakukan oleh seseorang. Ketakwaan menjadi indikasi dari kesehatan jiwa dan sekaligus sebagai tujuan dari pembinaan kejiwaan melalui ajaran-ajaran agama.

Tujuan dari pembinaan keagamaan yaitu membina moral atau mental seseorang ke arah keagamaan sesuai dengan ajaran-ajaran agama itu sendiri. Hal ini dimaksudkan agar setelah proses pembinaan seseorang dengan sendirinya menjadikan agama sebagai petunjuk, pedoman, serta menjadikan alat pengendali dari sikap, gerak-gerik dan tingkah lakunya dalam kehidupan sehari-hari. ${ }^{13}$

${ }^{10}$ Asep Karyana. Pendidikan Anak Berkebutuban Khusus Tunadaksa. (Jakarta: PT. Luxima Metro Media, 2013), hlm. 40-41.

11 Somantri, Sutjihati. Psikologi Anak Luar Biasa. (Bandung: Refika Aditama, 2006), hlm. 138. hlm. 504.

12 Tim Penyusun Kamus Pusat Bahasa. Kamus Besar Bahasa Indonesia. (Jakarta: Balai Pustaka, 2005),

13 Zakiyah DaradjatPendidikan Agama dalam Pembinaan Mental. (Jakarta: Bulan Bintang, 1982), hlm. 68.

20 | Afif Syaiful Mahmudin, - Membangun Inklusivitas Keberagamaan 
Bentuk dari pembinaan kegamaan ialah melaksanakan aktivitas dalam wujud kegiatan-kegiatan yang berkaitan dengan bidang agama yang terjadi di masyarakat dan menjalankan ajaran-ajaran agama dalam kehidupan sehari-hari. ${ }^{14}$ Bentuk-bentuk penyelenggaraan pembinaan kesehatan jiwa ini seperti mengerjakan sholat lima waktu dengan berjama'ah, membaca al-Qur'an bagi yang mampu, mengadakan dzikir bersama, melaksanakan kegiatan manaqib, istighosah, membaca sholawat bersama-bersama, mujahadah yang dipimpin oleh seorang imam dan lain sebagainya.

Menurut sudut pandang Islam, keberhasilan pembinaan keagamaan dapat ditemukan dari uraian sebagai berikut: a) Sakinah atau mapan, Thuma'ninah atau sikap tenang, serta Rahab atau rileks, b) al-kifayah atau memadai didalam aktivitas. Orang yang mengetahui potensi dan kelebihan yang dimilikinya maka akan mampu melakukan pekerjaan dengan baik, c) Penerimaan diri dan orang diluar diri sendiri, d) Mampu melakukan pemeliharaan dan penjagaan diri, f) Seseorang yang jiwanya sehat dia mampu bertanggung jawab pada dirinya sendiri, g) Mampu membayar kesalahan yang diperbuat, h) Mampu membangun kerjasama sosial dengan melandaskan kepada keterpercayaan dan saling memperbaiki satu dengan yang lain, i) Mempunyai cita-cita yang masuk akal, j) Memiliki rasa puas, gembira dan bahagia saat mendapat kenikmatan. ${ }^{15}$

\section{Bimbingan Fikih Ramah Difabel bagi Tuna Daksa dan Masyarakat}

\section{Metode Pembinaan}

a. Ceramah

Ceramah digunakan untuk menyampaikan konsep tentang: (a) pengantar umum tentang fikih difabilitas, (b) fikih thaharah, (c) praktik ibadah, dan (d) praktik wudlu, sholat fardlu serta pemahaman sekilas tentang puasa, zakat dan haji bagi difabilitas. Ceramah dikombinasikan dengan memanfaatkan laptop dan LCD untuk menayangkan materi powerpoint yang dilengkapi dengan gambar-gambar. Pemanfaatan laptop, LCD serta penayangan video praktik ibadah bagi penyandang difabel untuk membantu peserta pembinaan lebih mudah memahami materi. Adanya pembinaan melalui ceramah ini diharapkan dapat meningkatkan pengetahuan dan kesadaran penyandang tuna daksadan masyarakat tentang pentingnya praktik ibadah bagi difabel.

\footnotetext{
${ }^{14}$ Jalaluddin. Pengantar Ilmu Jiwa Agama. (Jakarta: Kalam Mulia, 1993), hlm. 56.

15 Abdul Mujib, Jusuf Mudzakir. Nuansa-Nuansa Psikologi Islam. (Jakarta: Raja Grafindo, 2002), hlm.
} $136-138$ 
Gambar 1. Ceramah oleh pemateri



b. Demonstrasi

Demonstrasi dilakukan oleh tim pemateri dari Pondok Pesantren "Lirboyo" Kediri sebagai narasumber, yakni dengan memberikan contoh praktik ibadah bagi penyandang tuna daksa dan masyarakat. Adanya pembinaan melalui demonstrasi diharapkan dapat meningkatkan pengetahuan dan kesadaran masyarakat dalam melakukan upaya pelaksanaan ibadah bagi tuna daksa.

Gambar 2. Demonstrasi oleh Pemateri






\section{Kondisi yang Diharapkan}

Kegiatan pengabdian kepada masyarakat ini mempunyai keinginan dan kepedulian agar para penyandang difabilitas dan para pendampingnya dapat melaksanakan kegiatan ibadah dengan benar sesuai ketentuan syariat. Harapan dari kegiatan ini adalah :

a. Menghasilkan pemahaman yang utuh dalam pelaksanaan ibadah fardlu bagi para penyandang tuna daksa. Sehingga mereka menyadari bahwa kewajiban itu tetap melekat kepada dirinya.

b. Meningkatkan kemampuan untuk melaksanakan ibadah fardlu yang sesuai dengan tuntunan syariat. Tidak harus lengkap dan sempurna pelaksanaan ibadahnya yang terpenting minimal telah terpenuhi syarat dan rukunnya.

c. Menghasilkan pengetahuan yang komprehensif bahwa melaksanakan ibadah fardlu bukanlah hal yang sulit untuk dilakukan oleh seorang muslim yang taklif.

d. Menghasilkan kondisi masyarakat sekitar yang dapat ikut memberikan konstribusinya dalam menggemblengeng para tuna daksa untuk selalu mengingatkan, memotivasi dan mendampingi dalam ibadah fardlu.

\section{Strategi Pelaksanaan Pembinaan}

Strategi yang digunakan dalam pembinaan fikih ibadahini ialah dengan melibatkan para penyandang tuna daksa beserta para masyarakat di "Rumah Kasih Sayang” Desa Krebet Kecamatan Jambon Ponorogo dengan menghadirkan pakar fikih yang mumpuni dalam mengisi kegiatan tersebut

Pembinaan ini diyakini mampu memberikan pengetahuan dan pemahaman tentang pentingnya fikih ibadah bagi kaum tuna daksa dan masyarakat. Topik pembinaan fikih ibadah ini sesungguhnya sudah didasarkan pada survey pendahuluan melalui peninjauan lokasi secara langsung maupun melalui wawancara dengan para tokoh yang terkait dengan "Rumah Kasih Sayang". Strategi pembinaanini bisa digambarkan dalam tabel logical frameworks sebagai berikut:

Tabel 3. Deskripsi Logical Frameworks

\begin{tabular}{|c|c|c|}
\hline \multicolumn{1}{|c|}{ Deskripsi } & Indikator & \multicolumn{1}{|c|}{ Asumsi } \\
\hline $\begin{array}{l}\text { Goal } \\
\text { yerhatian dan perlakuan sama dalam } \\
\text { pemenuhan hak-hak dan } \\
\text { kewajiban bagi } \\
\text { penyandang tuna daksa } \\
\text { dalam hal ibadah }\end{array}$ & $\begin{array}{c}\bullet \text { Melaksanakan } \\
\text { ibadah fardlu }\end{array}$ & $\begin{array}{c}\bullet \text { Kesadaran tuna daksa } \\
\text { terhadap ibadah fardu } \\
\text { meningkat }\end{array}$ \\
\hline $\begin{array}{l}\text { Purpose } \\
\text { Meningkatkanpemahaman } \\
\text { secara komprehensif }\end{array}$ & $\begin{array}{l}\text { Pengetahuan } \\
\text { pemahaman } \\
\text { terhadap fikih }\end{array}$ & $\begin{array}{l}\text { - Dapat melaksanakan } \\
\text { ibadah fardlu dengan } \\
\text { benar }\end{array}$ \\
\hline
\end{tabular}




\begin{tabular}{|c|c|c|}
\hline Deskripsi & Indikator & Asumsi \\
\hline $\begin{array}{l}\text { tentang fikih ibadah dan } \\
\text { mampu mempraktikkan } \\
\text { ibadah secara mudah bagi } \\
\text { tuna daksa }\end{array}$ & $\begin{array}{l}\text { ibadah bagi } \\
\text { tuna daksa }\end{array}$ & \\
\hline $\begin{array}{l}\text { Output } \\
\text { - Penyandang tuna daksa } \\
\text { dan masyarakat } \\
\text { mempunyai kemampuan } \\
\text { dalam pengetahuan dan } \\
\text { pelaksanaan ibadah fardlu }\end{array}$ & $\begin{array}{l}\text { - kemampuan } \\
\text { dalam } \\
\text { pengetahuan } \\
\text { dan } \\
\text { pelaksanaan } \\
\text { ibadah fardlu }\end{array}$ & $\begin{array}{l}\text { - Peningkatan kesadaran } \\
\text { dan kemampuan dalam } \\
\text { melaksanakan ibadah } \\
\text { fardlu melalui } \\
\text { penyampaian materi dan } \\
\text { praktik ibadah }\end{array}$ \\
\hline $\begin{array}{l}\text { Activities } \\
\text { - Studi pendahuluan } \\
\text { - Pembinaan Fikih Ibadah } \\
\text { bagi tuna daksa dan } \\
\text { masyarakat } \\
\text { - Identifikasi dampak } \\
\text { kegiatan pembinaan }\end{array}$ & $\begin{array}{l}\text { - Penetapan } \\
\text { topik dan } \\
\text { bentuk } \\
\text { kegiatan } \\
\text { - Tersedianya } \\
\text { narasumber } \\
\text { dan fasilitas } \\
\text { pembinaan } \\
\text { - Antusiasme } \\
\text { peserta } \\
\text { mengikuti } \\
\text { kegiatan }\end{array}$ & $\begin{array}{l}\text { - Kegiatan pembinaan } \\
\text { dilaksanakan secara } \\
\text { sistematis dan } \\
\text { komprehensif. }\end{array}$ \\
\hline
\end{tabular}

\section{Pelaksanaan Pembinaan Fikih Ibadah}

Tahapan pelaksanaan pembinaan fikih ibadah bagi penyandang dtuna daksa dan masyarakat di rumah kasih sayang Krebet Jambon Ponorogo ini dibagi menjadi tiga tahapan utama, yakni tahap persiapan, tahap pelaksanaan dan hasil pembinaan.

\section{a. Tahap Persiapan}

Tahap persiapan dimulai dari peninjauan awal lokasi pengabdian, pengurusan ijin dan menentukan pendekatan yang digunakan dalam pengabdian, kemudian disusul dengan koordinasi dengan pihak-pihak yang terlibat, kesepakatan tanggal pelaksanaan, persiapan alat dan media-media yang digunakan, jadwal dan penyesuaian materi serta pemateri, serta sosialisasi pada pengurus dan peserta yang terlibat

\section{b. Tahap Pelaksanaan}

Kegiatan pembinaan fikih ibadah ini dilakukan di "Rumah Kasih Sayang" Krebet Jambon Ponorogo. Program dilaksanakan secara bersama-sama di ruang utama Aula "Rumah Kasih Sayang" Jumlah total peserta yang mengikuti pembinaan ini sebanyak 25 orang. Dengan rincian 13 orang dari masyarakat dan 12 orang penyandang tuna daksa. 
Program pengabdian dilaksanakan dalam waktu dua hari yaitu hari Sabtu-Minggu tanggal 29 sampai 30 September 2018.

Gambar 3. Penyandang Tuna Daksa Mengikuti Pembinaan

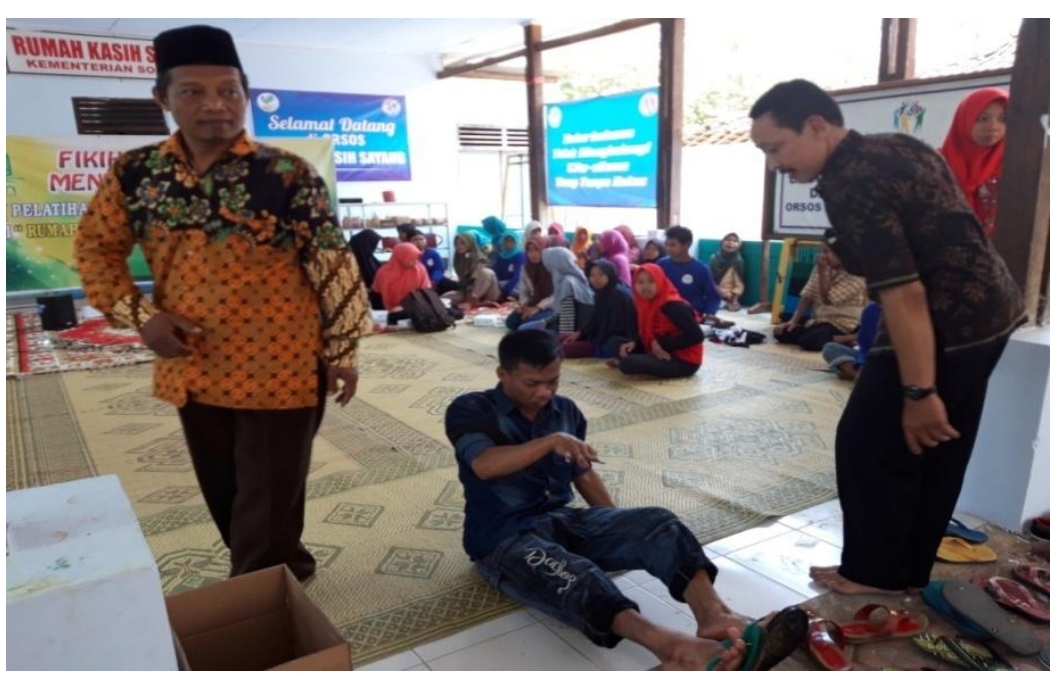

\section{c. Gambaran Umum Kegiatan}

Kegiatanpembinaan ini terdiri dari tiga tahapan, yakni assesment, kegiatan inti pembinaan, dan kegiatan evaluasi pasca kegiatan. Pada bagian ini dideskripsikan kegiatan inti pembinaanfikih ibadah di "Rumah kasih Sayang" Krebet Jambon Ponorogo. Assesment lapangan dilakukan pada hari Kamis, 13 September 2018. Dari hasil assesment diperoleh gambaran informasi mengenai peserta pembinaan, lokasi pelaksanaan kegiatan, strategi, dan uraian kegiatan yang akan dilaksanakan pada kegiatan pembinaan. Selanjutnya dilakukan sosialisasi kepada peserta melalui koordinasi dengan ketua "Rumah Kasih Sayang" yaitu Bapak Zaenuri dan penyampaian undangan.

Panitia juga bekerjasama dengan kader pendamping untuk membantu pelaksaaan pembinaan dengan menghadirkan Ust. Muhammad Irwan S.Pd.I. Alumni pondok pesantren Lirboyo Kediri serta membuka sesi diskusi atau tanya jawab setelah pelaksaan teori dan praktik fikih ibadah disampaikan.

Acara pembinaan dimulai pada hari Sabtu 29 September 2018 Pukul 09.00 WIB dan berakhir pada hari Kamis 14 September pukul 15.30 WIB Setelah peserta melakukan registrasi, diadakan pembukaan pembinaan yang diikuti oleh Pengurus "Rumah Kasih Sayang", Peserta, Kader Pendamping dan Masyarakat sertaNarasumber. Pembukaan acara dilaksanakan berkisar 45 menit yang berisi sambutan atau pengarahan dari Ketua "Rumah Kasih Sayang" sekaligus membuka acara pembinaan. Setelah acara pembukaan selesai, selama kurang lebih 15 menit diadakan persiapan tempat dan pengkondisian peserta. Setelah itu adalah acara inti pembinaan dengan narasumber Ust. Muhammad Irawan, S.Pd.I. dibantu dengan tim Fasilitator dan Kader Pendamping. Acara pada hari pertama berlangsung hingga pukul 14.00 WIB. Acara pada hari kedua dimulai pukul 09.00 WIB dengan narasumber yang sama akan tetapi lebih menekankan 
pada aspek praktik. Setelah praktik diadakan tanya jawab dan pendalaman materi baik dengan peserta ataupun masyarakat seta pengurus sebagai garda depan dalam mengawal peserta pasca pembinaan fikih ibadah. Kegiatan penutupan pembinaan pada pukul 15.00-15.30 WIB dengan ditutup langsung oleh Bapak Zaenuri selaku Ketua "Rumah Kasih Sayang".

Adapun secara lebih terperinci deskripsi kegiatan sebagaimana terlihat dalam schedule kegiatan di bawah ini :

Tabel 4. Rundown'Tahapan Kegiatan

\begin{tabular}{|c|c|c|}
\hline Tahapan & Uraian Kegiatan & Target Kegiatan \\
\hline \multirow{3}{*}{ 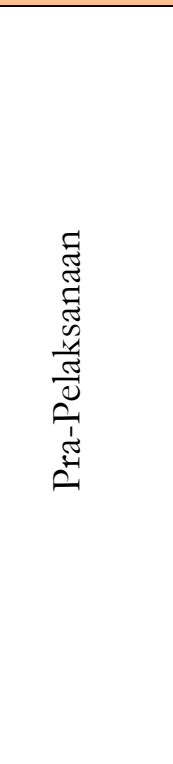 } & $\begin{array}{l}\text { 1. Tahap persiapan } \\
\text { meliputi perizinan, } \\
\text { materi dan pemateri }\end{array}$ & $\begin{array}{l}\text { Pada tahap ini diharapkan } \\
\text { perizinan, materi dan pemateri } \\
\text { serta draf kegiatan telah } \\
\text { diselesaikan }\end{array}$ \\
\hline & $\begin{array}{l}\text { 2. Pemetaan berbagai } \\
\text { permasalahan tuna } \\
\text { daksasekaligus } \\
\text { masyarakat yang di } \\
\text { "Rumah Kasih Sayang" }\end{array}$ & $\begin{array}{l}\text { Supaya diperoleh rincian } \\
\text { peserta penyandang tuna daksa } \\
\text { untuk memudahkan } \\
\text { penyampaian materi, } \\
\text { mendesain pembelajaran dan } \\
\text { praktik beribadah }\end{array}$ \\
\hline & $\begin{array}{l}\text { 3. Desain Pembelajaran } \\
\text { Fikih Ibadah dan Uji } \\
\text { Coba tahap Awal (pretest) }\end{array}$ & $\begin{array}{l}\text { Diperoleh desain Pembelajaran } \\
\text { Fikih Ibadah yang cocok } \\
\text { sehingga materi mudah untuk } \\
\text { dipahami dan dipraktikkan }\end{array}$ \\
\hline \multirow{3}{*}{ 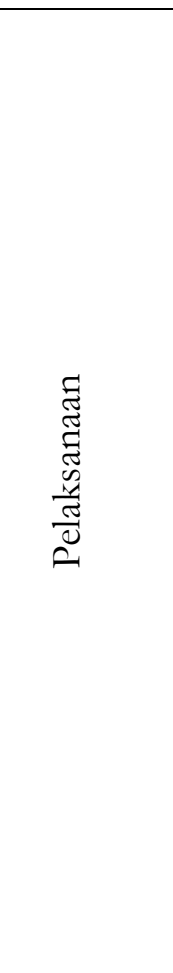 } & $\begin{array}{l}\text { 1. Pembinaan I terdiri dari } \\
\text { materi : } \\
\text { a. Pengantar umum } \\
\text { tentang Fikih Ibadah } \\
\text { b. Fikih Taharah } \\
\text { c. Praktik Taharah }\end{array}$ & $\begin{array}{l}\text { 1. Mengenal konsep Fikih } \\
\text { Ibadah } \\
\text { 2. Memberikan peningkatan } \\
\text { pemahaman fikih Taharah } \\
\text { dan Praktiknya bagi } \\
\text { penyandang tuna daksa }\end{array}$ \\
\hline & $\begin{array}{l}\text { 2. Pembinaan II terdiri dari } \\
\text { materi: } \\
\text { a. Sholat Fardlu } \\
\text { b. Praktik Salat fardlu }\end{array}$ & $\begin{array}{l}\text { 1. Memberikan tingkat } \\
\text { pemahaman yang lebih baik } \\
\text { tentang urgensi sholat } \\
\text { fardlu } \\
\text { 2. Dapat mempraktikan } \\
\text { sholat lima waktu dan } \\
\text { mengamalkan dalam } \\
\text { kehidupan sehari-hari }\end{array}$ \\
\hline & $\begin{array}{l}\text { 3. Pembinaan III terdiri } \\
\text { dari Materi: } \\
\text { a. Pemahaman sekilas } \\
\text { tentang Puasa, Zakat }\end{array}$ & $\begin{array}{l}\text { 1. Dapat mengetahui konsep } \\
\text { puasa, zakat dan haji bagi } \\
\text { penyandang tuna daksa } \\
\text { 2. Memahami Rukun Islam }\end{array}$ \\
\hline
\end{tabular}

26 | Afif Syaiful Mahmudin, - Membangun Inklusivitas Keberagamaan 


\begin{tabular}{|c|c|c|}
\hline & $\begin{array}{l}\text { dan Haji bagi } \\
\text { difabilitas } \\
\text { b. Evaluasi tahap II } \\
\text { sekaligus Praktik dari } \\
\text { Materi awal sampai } \\
\text { akhir (posttest) }\end{array}$ & $\begin{array}{l}\text { dan implementasinya dalam } \\
\text { kehidupan sehari-hari. }\end{array}$ \\
\hline 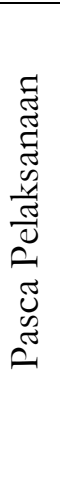 & $\begin{array}{l}\text { Pendampingan non } \\
\text { formal, analisis data dan } \\
\text { penyusunan laporan } \\
\text { pembinaan }\end{array}$ & $\begin{array}{l}\text { Diperoleh hasil (output) berupa } \\
\text { peningkatan pemahaman fikih } \\
\text { ibadah bagi penyandang tuna } \\
\text { daksa dan masyarakat sehingga } \\
\text { diharapkan tuna daksa dapat } \\
\text { mempraktikkan minimal rukun } \\
\text { Iman dan rukun Islam dalam } \\
\text { kehidupan sehari-hari secara } \\
\text { komprehensif. }\end{array}$ \\
\hline
\end{tabular}

Tabel 5. RundownKegiatan Inti Pembinaan

\begin{tabular}{|c|l|l|l|}
\hline \multicolumn{4}{|c|}{ Sabtu, 29 September 2018 } \\
\hline NO & \multicolumn{1}{|c|}{ WAKTU } & \multicolumn{1}{|c|}{ KEGIATAN } & \multicolumn{1}{|c|}{ KETERANGAN } \\
\hline 1. & $08.30-09.00$ & Registrasi Peserta & Panitia \\
\hline 2. & $09.00-09.45$ & $\begin{array}{l}\text { Pembukaan } \\
\text { Pembinaan }\end{array}$ & Panitia \\
\hline 3. & $09.45-10.00$ & Persiapan materi & Panitia \\
\hline 4. & $10.00-12.00$ & $\begin{array}{l}\text { Penyampaian materi } \\
\text { tentang konsep fikih } \\
\text { ibadah dan motivasi } \\
\text { beribadah }\end{array}$ & Narasumber \\
\hline 5. & $12.00-13.00$ & ISHOMA & Panitia \\
\hline 6. & $13.00-14.00$ & Fikih Thoharah & Narasumber \\
\hline 7. & $14.00-15.00$ & $\begin{array}{l}\text { Praktik Fikih } \\
\text { Thaharah }\end{array}$ & $\begin{array}{l}\text { Narasumber dan } \\
\text { Fasilitator }\end{array}$ \\
\hline NO & WAKTU & Minggu, 30 September 2018 \\
\hline 1. & $09.00-09.30$ & $\begin{array}{l}\text { Review Materi Fikih } \\
\text { Thaharah }\end{array}$ & Panitia dan Fasilitator \\
\hline 2. & $09.30-12.00$ & Fikih Sholat & Narasumber \\
\hline 3. & $12.00-13.00$ & ISHOMA & Panitia \\
\hline 4. & $13.00-14.00$ & $\begin{array}{l}\text { Lanjutan Praktik } \\
\text { Fikih Shalat }\end{array}$ & Narasumber \\
\hline 5. & $14.00-15.00$ & Pendalaman, Evaluasi & Narasumber dan \\
\hline
\end{tabular}




\begin{tabular}{|c|l|l|l|}
\hline & & dan Tanya Jawab & Fasilitator \\
\hline 6. & $15.00-15.30$ & Penutupan & Panitia \\
\hline
\end{tabular}

Evaluasi pasca kegiatan dilaksanakan untuk mengetahui sejauhmana keberhasilan kegiatan ditinjau dari: 1) target kehadiran jumlah peserta pembinaan; 2) tercapainya tujuan pembinaan dan ketercapaian target materi yang disampaikan; 3) kemampuan peserta dalam penguasaan materi; dan 4) evaluasi pelaksanaan kegiatan untuk mengetahui kepuasan peserta terhadap seluruh rangkaian kegiatan pembinaan melalui lembar evaluasi dan forum kritik dan saran.

Gambar 4. Praktik wudlu peserta pembinaan



Gambar 5. Praktik sholat peserta pembinaan




Gambar 6. Praktik sholat peserta pembinaan



\section{d. Hasil Pembinaan}

Pemahaman tentang fikih ibadah di "Rumah Kasih Sayang" Krebet Jambon Ponorogo sangat penting untuk diberikan mengingat selama ini berbagai kegiatan yang sering dilaksanakan di tempat tersebut adalah hard skill (Keterampilan) baik membatik, membuat tas, membuat keset, dan berbagai kecakapan lainnya, namun dalam aspek rohani belum pernah diberikan pembinaan secara khusus dan mendalam.

Hasil pelaksanaan pembinaan selanjutnya secara garis besar dapat dilihat dari penilaian beberapa komponen berikut, meliputi:

\section{1) Keberhasilan target jumlah peserta pembinaan}

Target jumlah peserta pembinaan sebanyak 35 orang, yang terdiri dari beberapa penyandang tuna daksadan penyandang difabilitas lain yang mampu mengikuti pelatihan sebagaimana data yang terdapat di "Rumah Kasih Sayang" Krebet Jambon Ponorogo. Dan 18 orang dari masyarakat. Namun dalam kenyataannya dalam pelaksanaan kegiatan yang hadir sebanyak 25 orang peserta hal ini karena beberapa faktor : a) Sebagian yang terdaftar tidak lagi aktif dalam kegiatan Jumat dan Minggu yang secara rutin dijadwalkan oleh Rumah Kasih Sayang. Dan untuk menginformasikan terkendala media dan jarak. b) Pada saat yang bersamaan ada kegiatan mendadak yakni santunan yatim piatu yang dilaksanakan oleh organisasi keagamaan setempat. Dengan demikian dalam pelaksanaan kegiatan pembinaan dapat dikatakan 12 orang dari keseluruhan jumlah penyandang tuna daksa hadir dan 13 orang dari masyarakat di sekitar "Rumah Kasih Sayang" tersebut.

\section{2) Ketercapaian Tujuan Pembinaan}

Tujuan pembinaan adalah membekali penyandang tuna daksa agar mampu melaksanakan ibadah dengan baik paling tidak terpenuhi syarat dan rukun dasar dalam beribadah khususnya tentang persoalan thaharah dan shalat lima waktu. Materi yang telah direncanakan, antara lain: Pemahaman konsep fikih ibadah, fikih taharah 
dan praktiknya bagi tuna daksa, sholat fardlu dan praktiknya bagi tuna daksa, serta beberapa motivasi dan pendalaman rukun Iman dan Islam. Semua materi pembinaan sebagaimana yang telah dirancang sebagaiman rundown acara dan alokasi waktu telah disampaikan secara keseluruhan.

\section{3) Kemampuan Peserta Dalam Penguasaan Materi}

Waktu pelaksanaan pembinaan yang relatif singkat, dan sulitnya menentukan tolak ukur sejauh mana pemahaman peserta terhadap penerimaan materi yang telah disampaikan mengingat beberapa hal: a) Tidak semua peserta mampu membaca dan menulis b) Bervariasinya masalah dari penyandang tuna daksa. Dari sini kesimpulan yang diperoleh adalah berdasarkan pre-test sebelum pelaksanaan pembinaan dan perbandingan praktek setelah materi fikih ibadah disampaikan. Secara umum pembinaan ini meningkatkan pengetahuan peserta mengenai Fikih ibadah khususnya persoalan ubudiyah dalam kehidupan sehari-hari yakni wudlu dan salat fardlu.

Tabel 6. Pemahaman Materi Pembinaan Hari I

\begin{tabular}{|c|c|c|c|c|c|c|c|c|}
\hline \multirow{2}{*}{ No } & \multirow{2}{*}{ Keterangan } & \multirow{2}{*}{$\mathrm{Jml}$} & \multicolumn{2}{|c|}{$\mathrm{Jml}$} & \multicolumn{4}{|c|}{ Keterangan } \\
\hline & & & $\mathbf{P}$ & $\overline{B P}$ & BS & $\mathbf{B}$ & $\mathrm{C}$ & $\mathbf{K}$ \\
\hline 1. & $\begin{array}{l}\text { Kesadaran } \\
\text { pentingnya Fiqih } \\
\text { Ibadah }\end{array}$ & 25 & 21 & 4 & 14 & 2 & 3 & 2 \\
\hline 2. & $\begin{array}{l}\text { Dapat } \\
\text { memahami syarat } \\
\text { dan rukun } \\
\text { wudhu }\end{array}$ & 25 & 24 & 1 & 17 & 3 & 3 & 1 \\
\hline 3. & $\begin{array}{l}\text { Dapat } \\
\text { Mempraktikkan } \\
\text { Wudhu dengan } \\
\text { Baik dan Benar }\end{array}$ & 25 & 19 & 6 & 11 & 4 & 2 & 2 \\
\hline
\end{tabular}

Evaluasi pemahaman peserta terhadap materi dilakukan melalui lembar ceklis dan observasi pada saat pelaksanaan praktik terkait dengan materi yang disampaikan oleh pemateri pada hari pertama. Dari hasil evaluasi terhadap pembinaan di hari pertama diketahui bahwa pemahaman peserta pembinaan bervariasi dari kategori kurang, cukup, baik, sampai dengan baik sekali. Kategorisasi kriteria dilakukan berdasarkan pengelompokan skor peserta pembinaan dengan skala 0 sampai dengan 100. Dari hasil analisis diketahui bahwa daya serap peserta khususnya terkait tiga hal yaitu ; pertama kesadaran akan pentingnya fiqih ibadah, kedua pemahaman peserta terkait dengan syarat dan rukun wudlu, dan yang ketiga pemahaman peserta dalam praktik wudlu. Dari tiga hal tersebut pemahaman peserta dapat dilihat sebagaimana tabel diatas. Dari tabel diatas kemudian kami sederhanakan menjadi empat katagori yaitu; Kurang, Cukup, baik dan Baik Sekali. Hasilnya secara lebih detail sebagaimana diagram di bawah ini: 
Gambar 1. Penyerapan Materi Pada Hari I Pembinaan



Dari gambar di atas dapat diketahui bahwa 17 orang (68\%) dari jumlah peserta termasuk dalam kategori kurang, 19 orang $(76 \%)$ dari jumlah peserta termasuk dalam katagori cukup, 20 orang $(80 \%)$ dari jumlah peserta termasuk dalam kategori baik, dan 9 orang $(36 \%)$ dari jumlah peserta termasuk dalam kategori pemahaman materi baik sekali.

Tabel 7. Pemahaman Materi Pembinaan Hari II

\begin{tabular}{|c|l|c|c|c|c|c|c|c|}
\hline \multirow{2}{*}{ No } & \multicolumn{1}{|c|}{ Keterangan } & \multirow{2}{*}{$\begin{array}{c}\text { Jml } \\
\text { Total }\end{array}$} & \multicolumn{2}{|c|}{ Jml } & \multicolumn{4}{|c|}{ Keterangan } \\
\cline { 5 - 9 } & & P & BP & BS & B & C & K \\
\hline kemahami & $\begin{array}{l}\text { kewaban sholat } \\
\text { fardlu }\end{array}$ & 25 & 58 & 7 & 12 & 22 & 10 & 14 \\
\hline 2. & $\begin{array}{l}\text { Mengetahui } \\
\text { Jumlah rakaat } \\
\text { sholat fardlu }\end{array}$ & 25 & 62 & 3 & 15 & 13 & 10 & 27 \\
\hline 3. & $\begin{array}{l}\text { Dapat melafalkan } \\
\text { bacaan-bacaan } \\
\text { dalam sholat } \\
\text { fardlu }\end{array}$ & 25 & 8 & 57 & 3 & 8 & 9 & 45 \\
\hline 4. & $\begin{array}{l}\text { Dapatmempraktik } \\
\text { kan pelaksanaan } \\
\text { sholat fardlu } \\
\text { secara munfarid }\end{array}$ & 25 & 62 & 3 & 54 & 9 & 1 & 1 \\
\hline 5. & Dapat & 25 & 21 & 44 & 6 & 13 & 20 & 21 \\
\hline
\end{tabular}




\begin{tabular}{|l|l|l|l|l|l|l|l|}
\hline $\begin{array}{l}\text { mempraktikkan } \\
\text { pelaksanaan sholat } \\
\text { fardlu secara } \\
\text { berjamaah }\end{array}$ & & & & & & & \\
\hline
\end{tabular}

Sebagaimana pelaksanaan pada hari pertama, evaluasi pemahaman peserta terhadap materi pada hari yang kedua dilakukan melalui lembar ceklis dan observasi atau pengamatan pada saat pelaksanaan praktik terkait dengan materi yang disampaikan pada hari kedua. Berdasarkan data tersebut dapat dianalisa bahwa pemahaman peserta terhadap materi yang disampaikan cukup bervariatif terlebih materi yang kedua lebih sulit dibandingkan dengan materi pada hari sebelumnya. Tolak ukur yang kami gunakan ada lima katagori meliputi: a)Pemahaman terhadap kewajiban sholat lima waktu.b) Hasil evaluasi terhadap pembinaan di hari pertama diketahui bahwa pemahaman peserta pembinaan bervariasi dari kategori kurang, cukup, baik, sampai dengan baik sekali. Kategorisasi kriteria dilakukan berdasarkan pengelompokan skor peserta pembinaan dengan skala 0 sampai dengan 100. Dari hasil analisis diketahui bahwa daya serap peserta khususnya terkait tiga hal yaitu; a)Kesadaran akan pentingnya fikih ibadah,b)Mengetahui bilangan rokaat sholat baik secara terperinci maupun global,c)Dapat melafalkan bacaan-bacaan salat fardlu,d) Mampu mempraktikkan sholat fardlu secara individu dan e)Dapat mempraktikkan sholat fardlu secara berjamaah. Hasilnya sebagaimana tersebut dalam kolom diatas. Angka 25 menunjukkan jumlah total peserta, kemudian (P) menunjukkan paham secara umum, (BP) adalah mereka yang belum paham sama sekali, kemudian bagi yang sudah paham kami rinci lagi menjadi empat $(\mathrm{K})$ menunjukkan kurang $(\mathrm{C})$ berati cukup, (B) menunjukkan pemahaman yang baik dan (BS) yang berarti tingkat pemahaman yang baik sekali atau hampir terpenuhi semua syarat dan rukunnya. Secara lebih detail sebagaimana penjelasan dalam kolom tersebut di atas. Namun secara lebih spesifik juga kami sederhanakan menjadi empat katagori yaitu ; Kurang, Cukup, baik dan Baik Sekali. Hasilnya secara lebih detail sebagaimana diagram di bawah ini: 
Gambar 2. Penyerapan Materi Pada Hari IIPembinaan



Dari gambar di atas dapat diketahui bahwa 20 orang (30.77\%) dari jumlah peserta termasuk dalam kategori kurang, 23 orang $(35.38 \%)$ dari jumlah peserta termasuk dalam katagori cukup, 16 orang $(24.62 \%)$ dari jumlah peserta termasuk dalam kategori baik, dan baru 6 orang $(9.23 \%)$ dari jumlah peserta termasuk dalam kategori baik sekali.

\section{4) Jalannya Pelaksanaan Pembinaan}

Pelaksanaan pembinaan secara keseluruhan dievaluasi untuk mengetahui seberapa jauh keberhasilan pembinaan ditinjau dari tingkat kepuasan pelayanan dalam kegiatan pembinaan. Kepuasan pelayanan yang dimaksud ditinjau dari segi narasumber atau pemateri, fasilitas kegiatan serta sarana dan prasarana. Hal tersebut sangat diperlukan guna meningkatkan layanan pada kegiatan-kegiatan pembinaan sejenis. Kepuasan didapat dari peserta setelah mengikuti pembinaan melalui kuesioner yang diberikan diakhir kegiatan. Setiap peserta mengisi kuesioner dan memberikan tanggapan terhadap pelayanan pembinaan dilihat dari berbagai aspek serta pelaksanaan pembinaan secara keseluruhan.

Adapun hasil evaluasi pelaksanaan pembinaan fikih ibadah di "Rumah Kasih Sayang" Krebet Jambon Ponorogo dapat dilihat dari tabel berikut :

Tabel 8. Hasil Evaluasi terhadap Pelayanan Narasumber

\begin{tabular}{|l|c|c|c|c|c|}
\hline \multirow{2}{*}{ Aspek yang diukur } & \multicolumn{5}{|c|}{ Prosentase Kepuasan (\%) } \\
\cline { 2 - 7 } & STP & P & CP & P & SP \\
\hline \multicolumn{1}{|c|}{$(1)$} & $(2)$ & $(3)$ & $\mathbf{( 4 )}$ & $\mathbf{( 5 )}$ & (6) \\
\hline 1. Kesesuaian Materi & 0 & 0 & 9 & 4 & 0 \\
\hline 2. Alokasi Waktu Setiap Materi & 0 & 0 & 7 & 6 & 0 \\
\hline
\end{tabular}




\begin{tabular}{|l|c|c|c|c|c|}
\hline \multirow{2}{*}{ Aspek yang diukur } & \multicolumn{5}{|c|}{ Prosentase Kepuasan (\%) } \\
\cline { 2 - 7 } & STP & P & CP & P & SP \\
\hline \multicolumn{1}{|c|}{$(\mathbf{1})$} & $\mathbf{( 2 )}$ & $\mathbf{( 3 )}$ & $\mathbf{( 4 )}$ & $\mathbf{( 5 )}$ & $\mathbf{( 6 )}$ \\
\hline 3. Cara Penyampaian Narasumber & 0 & 0 & 11 & 2 & 0 \\
\hline $\begin{array}{l}\text { 4. } \\
\text { Kesempatan Mengajukan } \\
\text { Pertanyaan }\end{array}$ & 0 & 0 & 5 & 5 & 3 \\
\hline $\begin{array}{l}\text { 5. Interaksi Narasumber dengan } \\
\text { Peserta dalam Pembinaan }\end{array}$ & 0 & 0 & 0 & 11 & 2 \\
\hline 6. Sistematika Materi & 0 & 0 & 8 & 5 & 0 \\
\hline \multicolumn{1}{|c|}{ Rata-rata } & $\mathbf{0}$ & $\mathbf{0}$ & $\mathbf{5 1}$ & $\mathbf{4 2}$ & $\mathbf{7}$ \\
\hline
\end{tabular}

Kriteria penilaian kepuasan menggunakan 6 kategori kriteria, yakni sangat tidak puas (STP), tidak puas (TP), cukup puas (CP), puas (P), dan sangat puas (SP). Namun demikian yang dijadikan objek dalam evaluasi ini adalah peserta dari masyarakat karena dari peserta penyandang tuna daksa belum mampu membaca dan menulis serta terbatas dalam kecerdasan intelaktualnya. Hasil evaluasi terhadap pemateri menunjukkan bahwa secara umum peserta merasa puas terhadap pelayanan yang diberikan oleh pemateri baik dari kesesuaian materi, alokasi waktu setiap materi, cara penyampaian narasumber, kesempatan mengajukan pertanyaan, interaksi narasumber dengan peserta dalam pembinaan, maupun sistematika penyampaian materi.

Daritabel diatas dapat diketahui bahwa secara umum kepuasan peserta berada pada kategori puas dengan rincian $42 \%$ responden menyatakan cukup puas, 51\% responden menyatakan puas, dan $7 \%$ responden menyatakan sangat puas. Secara lebih rinci dapat dilihat sebagaimana dalam gambar diagram dibawah ini: 
Gambar 3.Hasil Evaluasi terhadap layanan Narasumber



Tabel 9. Hasil Evaluasi terhadap Pelaksanaan Kegiatan

\begin{tabular}{|c|c|c|c|c|c|}
\hline \multirow{2}{*}{ Aspek yang diukur } & \multicolumn{5}{|c|}{ Persentase Kepuasan ( $\%)$} \\
\hline & STP & TP & $\mathrm{CP}$ & $\mathbf{P}$ & SP \\
\hline (1) & $(2)$ & (3) & $(4)$ & $(5)$ & $(6)$ \\
\hline 1. Konsumsi Pembinaan & 0 & 0 & 0 & 9 & 4 \\
\hline 2. Fasilitas Pembinaan & 0 & 0 & 0 & 10 & 3 \\
\hline $\begin{array}{l}\text { 3. Pelayanan administrasi } \\
\text { Pembinaan }\end{array}$ & 0 & 0 & 0 & 11 & 2 \\
\hline $\begin{array}{l}\text { 4. Penyelenggaraan seluruh } \\
\text { Pembinaan }\end{array}$ & 0 & 0 & 0 & 4 & 9 \\
\hline Rata-rata & 0 & 0 & 7 & 68 & 25 \\
\hline
\end{tabular}

Hasil evaluasi terhadap pelaksanaan kegiatan pembinaan menunjukkan bahwa secara umum peserta merasa puas terhadap pelayanan yang diberikan oleh panitia baik dari konsumsi pembinaan, fasilitas pembinaan, pelayanan administrasi pembinaan, maupun penyelenggaraan seluruh pembinaan.

Dalam hal ini yang kami berikan angket penilaian adalah peserta dari masyarakat dengan permasalahan yang sama yaitu peserta dari penyandang tuna daksa tidak bisa membaca dan menulis, dan komunikasi juga terbatas. Dari tabel diatas dapat diketahui secara umum bahwa kepuasan peserta berada pada kategori puas dengan rincian 7\% responden menyatakan cukup puas, 68\% responden 
menyatakan puas, dan 25\% responden menyatakan sangat puas. Untuk memperjelas dapat dilihat pada gambar berikut:

Gambar 4. Hasil Evaluasi terhadap Pelaksanaan Kegiatan

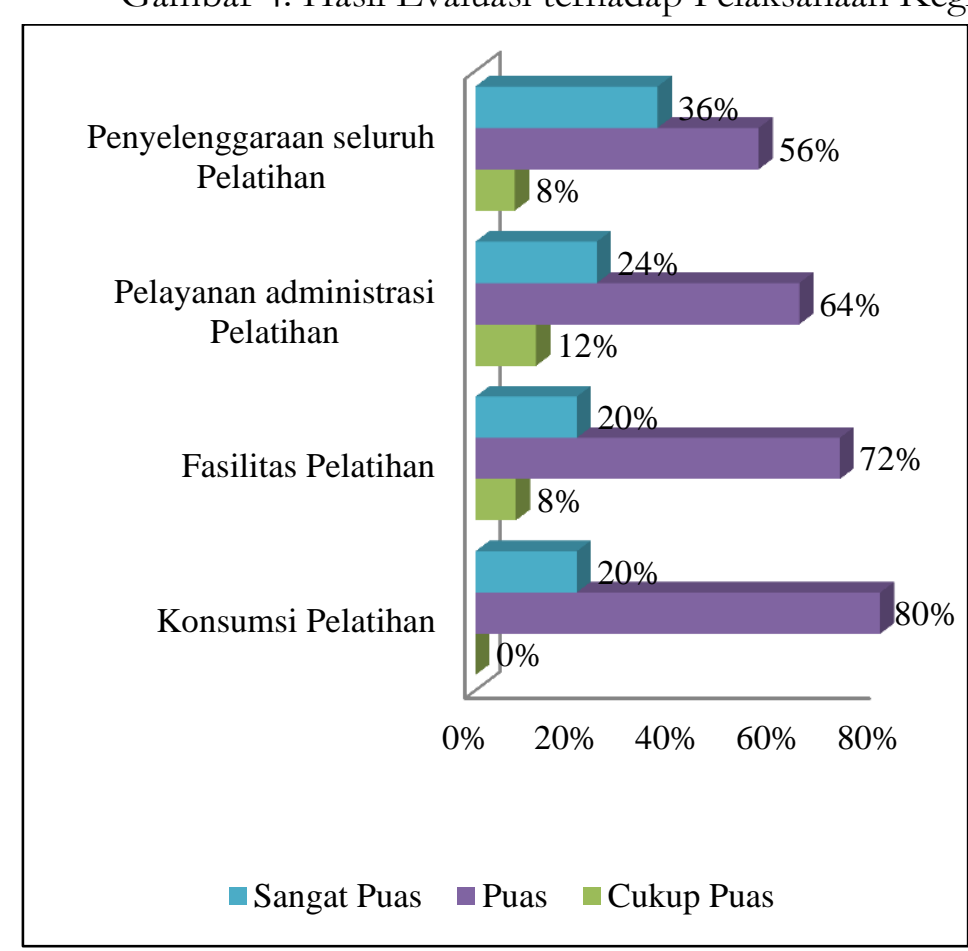

Dari tanggapan peserta secara langsung terhadap kegiatan, peserta puas dengan kegiatan yang diberikan karena memberikan manfaat, antara lain: meningkatkan pengetahuan tentang fikih ibadah baik bagi penyandang tuna daksa maupun masyarakat, hal ini disampaikan dalam acara dialog bersama, bahkan baik dari peserta maupun pengurus "Rumah Kasih Sayang" meminta untuk diadakan pembinaan secara terus-menerus serta memberi tindak lanjut pasca pembinaan dan memohon untuk sering-sering memberikan pendampingan terkait pelaksanaan aspek spiritual (ubudiyah) di "Rumah Kasih Sayang". Dengan berbagai manfaat yang dapat diperoleh, diharapkan masyarakat dan pengurus mampu menjadi motivator pengerak pasca pembinaanini khususnya dalam pengamalan pada kehidupan sehari-hari.

\section{5) Faktor Pendukung dan Penghambat Kegiatan}

Berdasarkan evaluasi pelaksanaan dan hasil kegiatan dapat diidentifikasi faktor pendukung dan penghambat pada pelaksanaan pembinaan fikih ibadah ini. Secara garis besar faktor pendukung dan penghambat adalah:

a) Faktor Pendukung

1) Dukungan dari ketua "Rumah Kasih Sayang"serta kader pendamping sangat besar dan antusias dalam menyambut dan mengikuti pembinaanfikih ibadah ini. Bahkan dalam ketua dan kader pendamping berharap kegiatan ini diadakan secara berkelanjutan.

2) Ketersediaan tenaga ahli dalam bidang fikih ibadah dari Ust. Muhammad Irwan, S.Pd.I Alumni Pondok Lirboyo Kediri serta kesanggupan masyarakat 
untuk mengawal implementasi praktik ibadah dalam kehidupan sehari-hari bagi warga penyandang tuna daksa di "Rumah Kasih Sayang".

3) Antusiasme dari ketua, kader pendamping maupun peserta yang tinggi dalam mengikuti kegiatan pembinaan fikih ibadah.

4) Lokasi pembinaan masuk dalam wilayah yang mendapatkan perhatian khusus terhadap persoalan difabilitas khususnya dari dinas sosial Kabupaten Ponorogo.

5) Adanya momen pelatihan-pelatihan dari pengurus "Rumah Kasing Sayang"yang selama ini hanya sebatas aspekhard skill bertambah kepada aspeksoft Skill bagi warga binaan difabel di "Rumah Kasih sayang”'Krebet Jambon Ponorogo.

b) Faktor Penghambat

1) Kendala waktu untuk pelaksanaan pembinaan yang mestinya bisa dimulai sejak pagi namun terkendala dari kedatangan peserta yang sebagian besar harus jalan kaki, dan terbatas sarana transportasi. Karena memang belum ada sistem antar jemput di "Rumah Kasih Sayang".

2) Mengingat luasnya materi tentang Fikih, pembinaan yang diselenggarakan selama 2 hari masih kurang mendalam ibarat kacang baru sebatas mengenal kulitnya belum sampai detail dan mendalam. Rekomendasi selanjutnya yaitu pembinaan diadakan rutin dan berkelanjutan di "Rumah Kasih Sayang" sebagai bagian dari kaum mustad'afin yang sangat perlu diperhatikan.

\section{Kesimpulan}

Dari pembinaan fikih ibadah yang diberikan kepada penyandang tuna daksa dan masyarakat sekitar lembaga "Rumah Kasih Sayang" menimbulkan peningkatan pemahaman tata-cara beribadah yang signifikan bagi tuna daksa, pembinaan ini dijalankan oleh mereka dengan suasana yang ringan dan menyenangkan, sehingga para tuna daksa mampu menerima hampir keseluruhan dari materi. Pembinaan keagamaan seperti ini sangat diperlukan bagi tuna daksa, karena selama ini baik dari Dinas-dinas pemerintahan maupun lembaga pemerhati difabilitas lainnya sama sekali belum menyentuh dari sisi kerohanian penyandang difabilitas khususnya tuna daksa. Selanjutnya, hasil dari pembinaan juga berimplikasi besar terhadap berubahnya cara pandang masyarakat sekitar kepada penyandang tuna daksa. Warga menjadi mengerti bahwa tuna daksa adalah manusia yang masih memiliki kewajiban untuk menjalankan kewajiban-kewajiban syariat seperti normalnya seorang Hamba Allah SWT. Pembinaan ini mempunyai harapan besar untuk kedepannya bagi masyarakat Desa Krebet, sikap keterbukaan dan inklusif yang sudah ditunjukkan setelah adanya pembinaan dapat dipertahankan sampai kapanpun sehingga Krebet yang dulunya dikenal sebagai "Kampung Idiot" yang skeptis terhadap difabel, menjadi lingkungan komunitas yang peduli difabel baik dalam segi hard skill maupun soft skill khususnya dalam hal keagamaan. 


\section{REFERENSI}

Daradjat, Zakiyah. (1982). Pendidikan Agama dalam Pembinaan Mental. Jakarta: Bulan Bintang. Jalaluddin. (1993). Pengantar Ilmu Jiwa Agama. Jakarta: Kalam Mulia.

Karyana, Asep. (2013). Pendidikan Anak Berkebutuhan Khusus Tunadaksa. Jakarta: PT. Luxima Metro Media.

Kristianto, Paulus Eko. (2017). Pengembangan Inklusifitas bagi Difabel Melalui Dakwah dalam Kerangka Filosofis Islam Kontemporer. Jurnal Pemberdayaan Masyarakat: Media Pemikiran dan Dakwah Pembangunan, Vol.1, No.2, 2017, 321-342

Merdiasi, Danella. (2013). Gambaran Tuna Daksa yang Bekerja. Jurnal NOETIC Psychology, Vol.3, No.2, Juli-Desember 2013, 163-184.

Mujib, Abdul \& Mudzakir, Jusuf. (2002). Nuansa-Nuansa Psikologi Islam. Jakarta: Raja Grafindo.

Pratiwi dan Hartosujono. (2014). Resiliensi pada Penyandang Tuna Daksa non Bawaan. Jurnal Spirits, Vol.5, No.1, November 2014, 48-54.

Somantri, Sutjihati. (2006). Psikologi Anak Luar Biasa. Bandung: Refika Aditama.

Tim Penyusun Kamus Pusat Bahasa. (2005). Kamus Besar Bahasa Indonesia. Jakarta: Balai Pustaka.

Widodo, Zandra dwanita eka ahmad malik p, indarto w, ismaryati. (2014). Meningkatkan potensi gerak kasar anak tunadaksa ringan melalui pendekatan bermain. Jurnal Rehabilitasi dan Remediasi Tahun 23, No.1, Juni 2014, 39-49. 